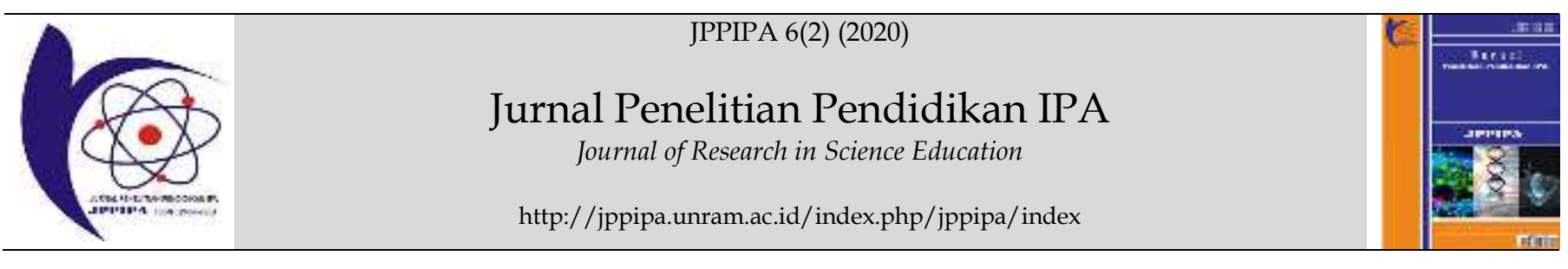

\title{
Validity of Assessment Attitude and Values System Based on Indonesian National Qualification Framework on Process Evaluation and Biological Learning Outcomes
}

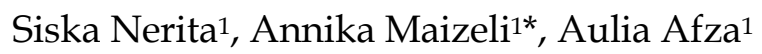 \\ ${ }^{1}$ Department of Biology Education, STKIP PGRI West Sumatra, Indonesia
}

DOI: $\underline{10.29303 / \text { jppipa.v6i2.439 }}$

\section{Article Info}

Received : April 30th, 2020

Revised : June $18^{\text {th }}, 2020$

Accepted: June 29th, 2020

\begin{abstract}
In the subject of the Evaluation of Process and Outcome of Biological Learning (EPOBL), carried out by applying guided discovery methods and the use of handout based on guided discovery. Problems found in the lecture process are pre-existing assessments that are not in accordance with the lecture process with guided discovery methods that use handouts based on guided discovery. The purpose of this study is to produce an assessment based on the Indonesian National Qualifications Framework that valid in the EPOBL subject. This research is a development research using the Plomp model. The instrument used is a questionnaire validity assessment of attitude and values system. The data analysis technique uses the percentage formula. The results of the study showed that the value of the attitude and values system assessment was $95.83 \%$ with very valid criteria. It can be concluded that the assessment of attitudes and values system based on the Indonesian National Qualifications Framework in Process evaluation and biology learning outcomes is very valid.
\end{abstract}

Keywords: validity; assessment attitude; Evaluation Learning

Citation: Nerita, S., Maizeli, A., \& Afza, A. (2020). Validity Of Assessment Attitude And Values System Based On Indonesian National Qualification Framework On Process Evaluation And Biological Learning Outcomes. Jurnal Penelitian Pendidikan IPA (JPPIPA), 6(2), 190-193. doi: https://doi.org/10.29303/jppipa.v6i2.439

\section{Introduction}

The issuance of the Indonesian National Qualifications Framework and the National Standards for Higher Education demands that the assessment of lectures include the assessment of attitudes, knowledge, general skills, and special skills. In the lecture the Process Evaluation and Biological Learning Outcomes, carried out by applying guided discovery methods and the use of handout based on guided. The method of discovery is considered as one of the teaching methods that allows students to achieve actual interactions with activities, so that they get different concepts and skills. The guided discovering method is a method that enables children to achieve actual interaction with activities; so he can acquire different concepts and skills (Saleh, 2018). Guided discovery methods are more effective than conventional methods in improving student learning achievement (Akani, 2017).

Problems found in the lecture process are preexisting assessments that are not in accordance with the lecture process with guided discovery methods that use guided discovery-based handouts. Therefore, assessment is needed in accordance with the lecture process so that it can measure students' abilities appropriately. Appropriate assessment is an assessment designed based on the Indonesian National Qualifications Framework. The development of the KKNI-based assessment aims to enable lecturers to 
measure students' abilities as a whole, which includes evaluating attitudes and values, general and special knowledge and skills (Maizeli, et al., 2019). The Indonesian National Qualifications Framework based assessment can evaluate students as a whole, which includes every domain of learning outcomes. Evaluation is very important to be carried out in ordedto find out what extent the educational process has been carried out. Assessment can be done at the beginning, middle or end of learning (Haqiqi et al, 2018), so that all aspects of affective, cognitive, and psychomotor assessment will appear in each process of student learning activities (Hartina, et al., 2020)

The Indonesian National Qualification Framework is a statement of the quality of Indonesian human resources whose qualification gap is based on the level of ability stated in the formulation of learning outcomes. The description of learning outcomes in the Indonesian National Qualification Framework contains four elements, namely elements of attitude and values, elements of work ability, elements of scientific mastery, and elements of authority and responsibility. The issuance of the National Standards of Higher Education the formulation of learning outcomes is included in one of the standards, namely the Standard of Graduates Competence. In the National Standards for Higher Education, learning outcomes consist of elements of attitudes, general skills, special skills, and knowledge (Directorate of Learning Kemenristek dikti: 2016).

The purpose of this study was to produce assessment tools (grids, rubrics and instruments) in the domain of attitudes and values system based on the Indonesian National Qualifications Framework in lectures on EPOBL Outcomes in the Biology Education department of STKIP PGRI Sumatera in valid.

\section{Method}

This research is a development research using the Plomp model (Plomp, 2007). This research is limited to the stage preliminary research by conducting curriculum analysis, prototyping phase (assessment design and validity test), namely to determine the level of validity and assessment of attitude and values. The instrument used is a questionnaire validity assessment of AAV. The AAV were validated by three validators. Validator 1 and validator 2 in the field of learning evaluation. Validator for 3 linguistic fields. The data analysis technique uses a percentage formula (V), namely

$$
\mathrm{V}=\frac{\text { item score obtained }}{\text { maximum score }},
$$

Based on the price of $\mathrm{V}$ obtained, the validity criteria can be determined which can be seen in Table 1 (Riduwan, 2007).

Table 1 . The validity criteria

\begin{tabular}{lll}
\hline No & Validation Value $(\%)$ & Category \\
\hline 1 & $0-20$ & Invalid \\
2 & $21-40$ & Less valid \\
3 & $41-60$ & Valid enough \\
4 & $61-80$ & Valid \\
4 & $81-100$ & Very valid \\
\hline
\end{tabular}

\section{Result and Discussion}

Validity of handouts based on quided discovery is obtained through the results of validation by experts or also called content validity. Content validity based on judgments about the sampling adequacy of test content. Judgments of the sampling adequacy of the test content. These judgments indicate the degree to which the content is represented by the items of the test; they thus establish the fit between the definition of a measurement operation and the actual operation that is devised (Fitzpatrick, 1983). The results of the study can be seen in Table 2 .

Table. 2 Validation Value Attitudes and Values Assessment by Validator

\begin{tabular}{llllll}
\hline Aspect & \multicolumn{2}{c}{ Validator } & $\begin{array}{l}\text { Ave } \\
\text { rage }\end{array}$ & Cate gory \\
\cline { 2 - 4 } & 1 & 2 & 3 & . \\
\hline Eligibility & 100 & 94.44 & - & 97.22 & very valid \\
content of & & 91.67 & 91.67 & 94.44 & very valid \\
Linguistic & 100 & 91.67 & - & 95.83 & very valid \\
Graffiti & 100 & 91.69 & & 95.83 & very valid \\
\hline
\end{tabular}

Based on Table 2 it can be seen that the assessment developed has met the validity requirements of a product. For aspects of content eligibility, the assessment validity value is 97.22 (very valid). For linguistic aspects, the assessment validity value is 94.44 (very valid). The validity value for graffiti is 95.83 (very valid). It can be concluded that the assessment developed is feasible to be tested in the next stage. Nugraha, et al (2013) explain that teaching materials that have met the validity category can be continued to the next stage of research.

The average value of the attitude and value assessment assessment validation in the aspect of feasibility is 97.22 (very valid). This shows that the assessment of attitudes and values system designed according to the 2013 university curriculum is based on the Indonesian National Qualifications Framework. In addition, the assessment is in accordance with the learning outcomes of the study program, the 
achievement of course learning, compatibility between assessment indicators with descriptors, descriptors are in accordance with the lecture process, and the observed aspects of assessment can measure student attitudes and values according to the learning process.

The importance of the eligibility requirements of this content is fulfilled by an assessment because it relates to the purpose of the design of the assessment. The assessment developed is expected to be able to measure the attitude and values of students in lectures, which means that it is related to the learning outcomes of the attitude domain. Appropriate assessment will produce the right learning outcomes. Assessment really is the bridge between teaching and learning (William, 2013). There are two main objectives of system affective evaluation: (1) To verify competencies in the affective domain, and (2) function as a method for changing behavior. Affective domains focus on receiving, responding, judging, organizing, and characterizing.

There are two primary purposes of affective evaluation systems: (1) to verify competence in the affective domain, and (2) to serve as a method to change behavior. Affective domains focus on receiving, responding, valuing, organizing, and characterization. (Kasilingam et al., 2014)

The average value of assessment validity in linguistic aspects is 94.44 (very valid). This shows that the assessment developed has clear letter shapes and sizes, the information provided is clear, in accordance with the good and correct Indonesian Spelling methods, and the use of simple and communicative language. Afza (2016) explains that good and clear language is a language that is in accordance with the communication needs in the language of learning. The use of good, clear and correct language will encourage good language skills among students both orally and in writing.

The average value of attitudinal assessment validity and values in the graphic aspect is 95.83 (very valid). This is because the assessment has an attractive appearance, such as cover, font usage, font type and size, suitability of layout or layout, and display design. The format or size of the product should be consistent and not have many variations. Ramadhani (2015) explains that a good format can make it easier for readers to understand the product being developed. Nerita, et al (2018) explain that the use of good, clear and correct language will encourage good language skills.

\section{Conclusion}

The conclusion of this study is the assessment of attitudes and values system based on the Indonesian National Qualifications Framework in the subject of the
Process Evaluation and Learning Outcomes of Biology which has been declared very valid.

\section{Acknowledgements}

Authors would like to thank STKIP PGRI Sumatera Barat for giving permission to conduct research and thank Riset dan Teknologi Pendidikan Tinggi for providing research grants

\section{References}

Afza, A. (2016). Development of oriented Biological Learning Devicesmodels Problem Based Learning (PBL) with Character Characteristics. BioConcetta Journal. 2 (1): 128-141. $\quad$ doi: https://doi.org/10.22202/bc.2016.v2i1.1492

Akani, O. (2017). Effect of Guided Discovery Method of Instruction And Studentsâ€ $€^{\mathrm{TM}}$ Achievement in Chemistry at the Secondary School Level in Nigeria. International Journal Of Scientific Research And Education, 5(02). Retrieved from http://ijsae.in/index.php/ijsae/article/view/94

Directorate of Learning Ministry of Research, Technology and Higher Education. (2016). Guide to Preparation of Higher Education Curriculum. Jakarta: Ministry of Research, Technology and Higher Education.

Fitzpatrick, A.R (1983). The Meaning of Content Validity. Applied Psychological Measurement. 7 (1). 3-13.

Hartina, L., Rosidin, U., \& Suyatna, A. (2020). Pengaruh Penerapan Instrumen Performance Assessment pada Pembelajaran IPA Berbasis Laboratorium Real terhadap Hasil Belajar Siswa. Jurnal Penelitian Pendidikan IPA, 6(1), 25-31. doi:https://doi.org/10.29303/ippipa.v6i1.299

Haqiqi, L., Ramdani, A., \& Zulkifli, L. (2018). Analisis Kemampuan Pendidik dalam Menerapkan Penilaian Autentik Pada Mata Pelajaran Biologi Kelas X IPA SMA di Kabupaten Lombok Timur. Jurnal Penelitian Pendidikan IPA, 4(1). doi:https://doi.org/10.29303/jppipa.v4i1.60

Kasilingam, G., Ramalingam, M., and Chinnavan, E. (2014). Assessment of Learning Domains to Improve Student's Learning in Higher Education. Journal of Young Pharmacists. 6 (4): 2733. doi:10.5530/jyp.2014.1.5

Maizeli, A., Nerita, S., and Afza, A. (2019). Assessment Biology Learning Prcticality Based on Indonesian National Qualification Framework on Biology Learning and Evaluation.International. Journal of Research in Engineering and Science (IJRES). 7(2): 611. 
Nerita, S., Hartati, Y., Maizeli, A., \& Afza, A. (2018). Validitas Handout Berbasis Penemuan Terbimbing Pada Perkuliahan Evaluasi Proses dan Hasil Belajar Biologi. Jurnal Penelitian Pendidikan IPA, 4(2). doi:https://doi.org/10.29303/ippipa.v4i2.131.

Nugraha, D.A., Achmad, B \& Supartono. (2013). Media Reaksi Redoks Bervisi SETS Berorientasi Konstruktivistik. Journal of Innovative Science Education. 2 (1).

Plomp, T. (2007). Educational Design Research: an Introduction. Proceedings of the Conducted at the East China Normal University Seminar, Shanghai (PR China). November 23-26 p 9-36

Ramadhani, W.P., and Mahardika, I.K. (2015). Kegrafikaan Physics Learning Module Based on Multi-representation. Proceedings of the National Seminar on Physics and Learning. 85-91.

Riduwan. (2007). Easy Learning Research for Teachers, Employees, and Beginner Research. Bandung: Alfabeta.

Saleh, E.A.A., (2018). The Effect of Using the Guided Discovery Method on Enabling the Students with Intellectual Disability to Acquire some PreAcademic Mathematical Concepts in the Kingdom of Saudi Arabia. International Journal of English Linguistic. 8 (3): 108-130. doi: http://doi.org/10.5539/ijel.v8n3p108

William, D. (2013). Assessment: The Bridge between Teaching and Learning. Voices from the Middle, 21(2). p 15-20. 